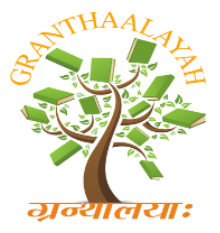

INTERNATIONAL JOURNAL OF RESEARCH GRANTHAALAYAH

A knowledge Repository

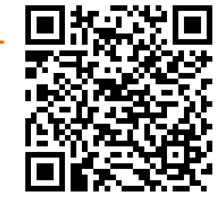

\title{
MASS MEDIA IN DISSEMINATING ENVIRONMENTAL AWARENESS
}

\author{
Vibha Singh Kushwaha
}

Matushri Ahilyadevi Teachers' Education Institute, Sulakhedi, Indore (M.P.)

\begin{abstract}
Developments in the field of science and technology while paving way for too many revolutions on the one hand had resulted in serious environmental problems on the other. At this juncture, the role of mass media becomes pertinent in spreading environmental awareness. The approach to entertainment- education can be a very promising one in creating environmental awareness via the usage of media such as, newspapers and magazines, radio, television and Internet.
\end{abstract}

Keywords:

Environmental awareness, Mass Media, environmental problems.

\section{INTRODUCTION}

Media has a greater role in promoting environmental education. Today, as environmental problems are escalating with the ever increasing rise in population, there is an urgent need to preserve the environment and improve it qualitatively not only for the future generations. The growing concern for the environmental issues is also evident from the fact that many national and international reports, conferences, campaigns, organizations had frequently come up for protecting and banning activities that endanger environment.

These include, UN Conference on the Human Environment, Stockholm Report 1972, Belgrade Charter 1975, Tbilisi Report 1977, Brundtland Commission (1983) and Agenda 21 of Rio Declaration 1992, etc. to name a few. However, these are only superficial and external measures that do not get to the root of the problems. The United Nations Conference on Environment and Development held in Rio de Janeiro, Brazil in 1992, popularly known as the Earth Summit, also adopted an action plan for Sustainable Development, Agenda 21. The Chapter 36 which is devoted to education states, that "Education is critical for promoting sustainable development and improving the capacity of people to address environment and development issues"

Media as a force can play an active role in alerting people about environmental damages, corporate failure to meet its legal obligations, truthful analysis of new legislations and steps for protection and preservation of environment. Studies conducted by Arcury et al. (1987); Ostman \& Parker (1986, 1987); Brothers. Al. (1991); Hausbeck et. Al (1992); Chan (1996, 1999); Prathap \& Ponnusamy (2006); and Kappor (2011) had also emphasized the importance of different types of media such as newspapers, radio, television, electronic or print, etc. in creating environmental awareness among the people of different communities belonging to urban and rural areas.

The same problems arise, although to a lesser degree, in dealing with major transformations such as population growth and urbanization .However, there is a need for change the present media approaches and structure. Only then, this important sector would be in a better position to reflect 
the goals, aspirations and content of the environmental education. Emotionalism and exaggeration in media reporting is a frequent source of difficulty. The press is understandably drawn to those with the most extreme view. Disagreements and conflicting views between specialists are also "newsworthy" and are skillfully exploited. More moderate and reasoned voices often go unheard in the din. Extreme positions, while they may be useful in catching the public attention and alerting it to pending dangers. Make it difficult to move from declarations and debate into action.

It has to be recognized that neither individuals nor societies are ready or even able to change thei8r habits and behaviours overnight. Proposals for change, if they are to be effective, have to be feasible. Both the messages and the messengers have to appear credible and responsible.

According to the International Commission on Education for the Twenty-first Century of UNESCO, 1996, there are six underlying universal principles concerned with education:

1. Education is a basic human right and a universal human value and should be made available over the entire lifetime of each individual.

2. Education, both formal and non-formal, must serve society as in instrument for fostering the creation, advance and dissemination of knowledge.

3. The triple goals of equity, relevance and excellence must prevail in policy-making, planning and practice.

4. Renewal and reform of education must be based on a good understanding of successful practices and proceed from specific local contexts.

5. All approaches to education development, however different, must take into account basic and agreed-upon values and concerns of the international community and the United Nations system.

6. Education is the responsibility of the whole of society.

\section{NEWSPAPERS \& MAGAZINES}

Newspapers have always been the perfect accompaniment with the morning, cup of tea. They act as a motivational source, for example, when they enlighten the farmers on the negative consequences of the use of pesticides, ways of introducing organic farming, new agricultural technologies, etc. As a result of these exposures and subsequent public pressures, local authorities, governments, industries and other units are forced to change their plans and practices, to strongly enforce laws and regulation, and to abandon those development projects whose environmental and social costs outweighs any benefits. Similarly, the environmental magazine like "Down to Earth" had been found to cover a broad variety of environment related topics (ranking from policy to science, from local to global level) and their scientific background,

\section{RADIO}

Radio is cheap, most easily accessible and its signals cover almost whole of the country. It has been noted that Delhi FM was broadcasting two weekly programs on environment, "KinareKinare" and "Ao Dilli Savaren"on being motivated by the Ministry of Environment \& Forests. At the national level, the news on environmental aspects are very scarce and if they are broadcast they are most often at the regional level.

\section{TELEVISION}

Mass media, especially TV, for promotion Government is now increasing interested in allocating prime TV slots to environmental program on TV regarding environmental issues. Most environmental documentaries shown on TV today attract few viewers because of the academic or obscure manner in which they are presented. 
There are some channels like, Discovery Channel, National Geographic Channel and Animal Planet Channel which are broadcasting exclusively on endangered species, wildlife, sea life, etc. The programs like "Virasat" , "Race to Save the Plant", quiz show named "Terraquiz" ,"Earth" was telecast by the Ministry of Environment \& Forest in cooperation with Doordashan. In addition to that BBC's "Earth Report" offered exclusive information on environment and with the daily broadcast of "The New Adventures of Captain Plant" on Cartoon Network there was at least one program on environmental issues especially designed for children.

\section{INTERNET}

The Internet's huge reach and accessibility make it one of the best resources for people all over the world to find information about climate change, environmentalism, and how to be green. Internet is nowadays used more frequently to encourage environmental awareness as it provides opportunity to the people to respond and participate immediately. Social media sites such as "Twitter", "Face book", etc. are very good for sharing news, information, and articles and thus, most useful for staying up-to-date on environmental topics. The Internet has converged traditional media with new media, which has produced on eclectic and multifaceted resource for users to get content about environmentalism.

\section{CONCLUSION}

Media play an important role in forming the positive attitudes of the public towards the environment. Media's role in increasing environmental awareness of the population is an enormous one as it reaches a vast percentage of India's complex society. There is now a question whether modern education as provided would adequately equip the young generation to take up the future challenges of the technology-driven, environmentally-degraded globalized world.

\section{REFERENCES}

1. Annual Report (2004-2005). Education and Awareness Ministry of Environment \& Forests, India

2. Arcury, T.A., Scollay, SJ. \& Johnson, T.P. (1987) Sex Differences in Environmental Concern and Knowledge: The Case of Acid Rain. Sex Roles, 16, 463-472

3. Brothers, C.C., Fortner, R.W.\& Mayer, V.J. (1991). The Impact of Television News on Public Environmental Knowledge Journal of Environmental Education, 22 (4), 22-29.

4. Chan, K. (1996). Environmental Attitudes and Behaviors of Secondary School Students in Hong Kong The Environmentalist, 16, 297-306.

5. Chan, K. (1999). Mass Media and Environmental Knowledge of Secondary School Students in Hong Kong The Environmentalist 19,85-97.

6. Das, Nandita (2001) A Study on Social and Environmental Impact of TV and Radio Programmes. Center of Media Studies, New Delhi

7. Hausbeck, K.W., Milbrath, L.W., \& Enright, S.M. (1992). Environmental Knowledge, Awareness and Concern Among 11th-Grade Students: New York State, Journal of Environmental Education, 24-34.

8. Hoerisch, H. (2002) A comparative Study on Environmental Awareness and Environmentally Beneficial Behavior in India. For CMS ENVIS Centre, New Delhi

9. Kapoor, N. (2011). Role of Mass Media in Promotion of Environmental Awareness along with Skill Development among the Rural People of Shringverpur, Allahabad District, India Psrcentre.org/images/extra images/1211545.pdf

10. Kumari, A. (1999), Rural Women's Perception about Mass Media Effectiveness. Journal of Extension Education 10 (1), 2265-2268. 
11. Ostman, R.E. \& Parker, J.L. (1986). A Public's Environmental Informational Sources and Evaluations of Mass Media Journal of Environmental Education, 18 (2), 9-17

12. Prathap, D.P. \& Ponnusamy, K.A. (2006) Effectiveness of Four Mass Media Channels on the Knowledge Gain of Rural Woman. Journal of International Agricultural and Extension Education, 13 (1), 73-81. 